\title{
Eksekusi Putusan Pengadilan Hubungan Industrial: Beberapa Catatan Masukan RUU Hukum Acara Perdata
}

\author{
Dwi Maryono \\ Dinas Ketenagakerjaan, Propinsi Jawa Tengah, \\ disnakertrans@jatengprov.go.id \\ Muhamad Azhar \\ Fakultas Hukum, Universitas Diponegoro \\ azhar@live.undip.ac.id
}

\begin{abstract}
This paper aims to describe the existence of the decisions of the industrial relations court, especially related to the execution of the decisions of the industrial relations court. This article only elaborates on the empirical issues that have become the problem in carrying out the execution of the decisions of the industrial relations court. The interim findings show that efforts must be made to provide space for the execution of the industrial relations court. So far, the execution of barren industrial relations court decisions has not been implemented. One reason is the lack of regulation on the procedure for the execution of industrial relations court decisions in Law No. 2 of 2004 concerning the Settlement of Industrial Relations Disputes. The solution is left to the execution procedure at Herzien Inlandsch Reglement (HIR) and Rechtsreglement voor de Buitengewesten (Rbg).
\end{abstract}

Keywords: Decision Execution, Industrial Relations Court, Indonesian Civil Procedure

\begin{abstract}
Abstrak
Tulisan ini bertujuan untuk menguraikan keberadaan putusan pengadilan hubungan industrial, khusunya terkait dengan eksekusi putusan pengadilan hubungan industrial. Tulisan ini hanya menguraikan sekilan permasalahan empiris yang menjadi kendalam dalam melaksanakan eksekusi putusan pengadilan hubungan industrial. Hasil temuan sementara menunjukan bahwa harus ada upaya untuk memberikan ruang bagi pelaksanaan eksekusi pengadilan hubungan industrial. Selama ini eksekusi putusan pengadilan hubungan industrial mandul, tidak dapat dilaksanakan. Salah satu penyebabnya adalah tidak adanya pengaturan tata cara eksekusi putusan pengadilan hubungan industrial dalam Undang Undang Nomor 2 tahun 2004 tentang Penyelesaian Perselisihan Hubungan Industrial. Penyelesaiannya diserahkan kepada tatacara eksekusi pada Herzien Inlandsch Reglement (HIR) dan Rechtsreglement voor de Buitengewesten (Rbg).
\end{abstract}

Kata Kunci: Eksekusi Putusan, Pengadilan Hubungan Industrial, RUU Hukum Acara Perdata

\section{A. Latar Belakang}

Perlindungan hukum kepada buruh di Indonesia ditempatkan dalam dua wilayah hukum yaitu hukum publik dan hukum privat. Hukum publik lazimnya dirumuskan sebagai hukum yang mengatur kepentingan umum dan mengatur kepentingan penguasa dan warga negaranya. Hukum publik ini adalah keseluruhan peraturan yang merupakan dasar negara dan mengatur pula bagaimana cara negara melaksanakan tugasnya. Jadi hukum publik merupakan 
perlindungan kepentingan negara, oleh karena memperhatikan kepentingan umum maka pelaksanaan peraturan hukum publik dilakukan oleh penguasa.

Hukum privat adalah hukum antar perorangan yang mengatur hak dan kewajiban perorangan yang satu terhadap yang lain di dalam hubungan keluarga dan di dalam pergaulan masyarakat, pelaksanaannya diserahkan kepada masing-masing pihak. Contoh dari hukum publik yaitu hukum pidana sedangkan contoh dari hukum privat ini adalah hukum perdata. Jadi peraturan perundang-undangan di Indonesia di dalam memberikan perlindungan kepada buruh dengan memberikan sanksi yang bersifat perdata maupun pidana kepada pengusaha yang melanggar hak-hak buruh.

Contoh perlindungan hukum bagi buruh yang berada di wilayah hukum privat adalah ketentuan dalam undang-undang nomor 13 tahun 2003 tentang Ketenagakerjaan yang mengatur tentang Pemutusan Hubungan Kerja (PHK) yaitu apabila pengusaha melakukan PHK secara sewenang-wenang kepada buruh atau melakukan PHK bukan karena sebab-sebab yang diperbolehkan oleh peraturan perundang-undangan maka PHK tersebut dapat dikategorikan sebagai PHK yang tidak sah dan buruh harus dipekerjakan kembali. Tetapi untuk melaksanakan ketentuan tersebut apabila pengusaha tidak mau mempekerjakan kembali buruh maka buruh yang bersangkutan harus melakukan upaya hukum sendiri dalam bentuk mengajukan gugatan ke pengadilan hubungan industrial agar pengadilan menyatakan PHK tersebut tidak sah dan meminta untuk dipekerjakan kembali. Jadi dalam melaksanakan sanksi atau ketentuan tentang PHK yang tidak sah tersebut buruh harus berupaya sendiri dan nyaris tidak ada campur tangan pemerintah.

Contoh yang lain yaitu apabila pengusaha melakukan PHK terhadap buruhnya karena sebab-sebab yang dibenarkan oleh peraturan perundang-undangan maka pengusaha harus memberikan hak-hak buruh yang di PHK yang salah satunya hak-hak buruh yang berbentuk uang yang jenis dan cara penghitungan hak-hak tersebut telah ditentukan dalam peraturan perundang-undangan ketenagakerjaan. Apabila pengusaha tidak memberikan hak-hak tersebut atau memberikan hak-hak tersebut tetapi kurang dari jumlah yang ditentukan oleh peraturan perundang-undangan maka untuk mendapatkan hak-hak tersebut buruh yang bersangkutan harus mengajukan gugatan ke pengadilan hubungan industrial agar hak-hak tersebut diberikan. Di sini sekali lagi buruh juga harus berupaya sendiri untuk mendapatkan hak-haknya.

Sanksi-sanksi tersebut bersifat perdata atau berada di wilayah hukum privat, konsekuensinya penerapan sanksinya tergantung dari para pihak yaitu buruh dan pengusaha. Apabila sanksi tersebut tidak dipenuhi oleh pengusaha maka buruh harus menempuh prosedur hukum privat agar sanksi tersebut dapat dipaksakan. Dalam hal ini buruh harus menempuh prosedur perselisihan hubungan industrial mulai perundingan bipartit, mediasi, pengajuan gugatan dan pemeriksaan di pengadilan hubungan industrial, Kasasi ke Mahkamah Agung sampai dijatuhkannya putusan yang mempunyai kekuatan hukum tetap (inkracht). 


\section{B. Permasalahan}

Berdasarkan latar belakang di atas, maka fokus pembahsan dalam tulisan singkat ini adalah mencari tahu alternatif solusi agar eksekusi putusan Pengadilan Hubungan Industrial yang sudah berkekuatan hukum tetap dapat berjalan dengan baik sehingga buruh dapat memperoleh hak-haknya. Apa yang bisa dilakukan dalam rangka memberikan masukan untuk Rancangan Undang-undang Hukum Acara Perdata khususnya yang terkait dengan eksekusi.

\section{Pembahasan}

Dalam proses hukum privat ini buruh harus mempertahankan haknya sendiri dan nyaris tidak ada campur tangan dari pemerintah. Dalam proses hukum privat ini buruh harus aktif menempuh proses yang harus dijalani dan harus membiayai sendiri. Karena harus mempertahankan haknya sendiri maka seringkali buruh menyerah ditengah jalan dalam mempertahankan haknya karena tidak mampunyai pengetahuan dan kemampuan untuk beracara di pengadilan atau kekurangan biaya.

Pemeriksaan perkara di Pengadilan Hubungan Industrial diakhiri dengan putusan, akan tetapi dengan dijatuhkan putusan saja belumlah selesai persoalannya. Sering terjadi bahwa pihak yang dikalahkan dalam hal ini pengusaha tidak mau melaksanakan putusan hakim secara sukarela sehingga diperlukan bantuan dari pengadilan untuk melaksanakan putusan tersebut secara paksa. Pihak yang dimenangkan dalam putusan dalam hal ini buruh dapat mohon pelaksanaan putusan (eksekusi) kepada pengadilan yang akan melaksanakannya secara paksa (execution force)

Apabila buruh dimenangkan dalam putusan Pengadilan Hubungan Industrial sekalipun putusan tersebut telah mempunyai kekuatan hukum tetap (inkracht) tidak secara otomatis buruh akan mendapatkan hak-haknya sesuai dengan apa yang ada dalam putusan tersebut karena apabila pengusaha tidak mau melaksanakan putusan tersebut maka buruh masih harus mengajukan permohonan eksekusi. Tahap-tahap proses eksekusi putusan pengadilan meliputi peringatan (aanmaning), sita eksekutorial, dan penjualan lelang. Dalam setiap tahapan eksekusi tersebut buruh harus aktif dengan mengajukan permohonan kepada Ketua Pengadilan Negeri.

Seringkali buruh dalam beberapa kasus khususnya kasus-kasus Pemutusan Hubungan Kerja (PHK) sudah berupaya menempuh proses perselisihan hubungan industrial mulai dari perundingan bipartit, mediasi, pengajuan gugatan ke Pengadilan Hubungan Industrial, kasasi ke Mahkamah Agung sampai dengan dijatuhkannya putusan oleh hakim tetapi buruh tetap tidak mendapatkan hak-haknya walaupun dalam putusan tersebut buruh dimenangkan dan putusan tersebut telah mempunyai kekuatan hukum tetap (inkracht) karena putusan-putusan tersebut tidak dapat dilaksanakan atau dieksekusi. 
Pemerintah telah banyak memberikan perlindungan kepada buruh dalam hal Pemutusan Hubungan Kerja (PHK) melalui peraturan perundang-undangan. Tetapi dalam prakteknya ternyata peraturan-peraturan tersebut sulit dilaksanakan. Dalam prakteknya buruh seringkali tidak mendapatkan hak-haknya ketika di PHK khususnya hak-hak yang berupa uang baik Uang Pesangon, Uang Penghargaan Masa Kerja, Uang Penggantian Hak dan atau Uang Pisah.

Padahal untuk memperoleh hak-hak tersebut seringkali buruh sudah menempuh proses yang panjang dan melelahkan melalui prosedur Penyelesaian Perselisihan Hubungan Industrial mulai dari perundingan bipartit, mediasi, pengajuan gugatan ke Pengadilan Hubungan Industrial, kasasi ke Mahkamah Agung sampai dengan dijatuhkannya putusan oleh hakim.

Seolah-olah putusan yang telah dijatuhkan hakim tersebut tidak mempunyai daya guna ketika pengusaha yang dihukum untuk memberikan hak-hak buruh yang di PHK dalam putusan tersebut menolak untuk memberikannya. Sehingga sia-sia upaya panjang yang telah ditempuh buruh yang di PHK untuk mendapatkan hak-haknya.

Bagi buruh Pemutusan Hubungan Kerja itu sendiri sudah merupakan sesuatu beban yang sangat memberatkan bagi dirinya apalagi jika pekerjaan tersebut merupakan satu-satunya sumber nafkah bagi dirinya. Sehingga setelah di PHK kehidupannya dirinya dan keluarganya ke depan menjadi tidak menentu. Satu-satunya harapan untuk sementara menyambung kehidupannya ke depan adalah dengan mnggunakan hak-haknya yang berbentuk uang yang seharusnya dia peroleh berdasarkan peraturan perundang-undangan. Dengan uang tersebut buruh dapat memenuhi sementara waktu kebutuhannya beberapa waktu ke depan sambil mencari pekerjaan yang baru atau memulai usahanya sendiri. Apabila setelah dia di PHK uang tersebut juga tidak dia dapatkan maka semakin sengsaralah dia dan semakin tidak pasti kehidupannya ke depan.

Amar putusan hakim dapat pula berupa pernyataan bahwa pemutusan hubungan kerja yang dilakukan oleh pengusaha kepada pekerja dinyatakan tidak sah dan menghukum pengusaha untuk mempekerjakan kembali pekerja yang bersangkutan. Hal ini dapat terjadi jika pemutusan hubungan kerja tidak dengan alasan yang dibenarkan oleh undang-undang. Namun demikian, dalam prakteknya putusan hakim yang memerintahkan pengusaha untuk mempekerjakan kembali pekerja adalah sulit untuk dipaksakan kepada pengusaha.

Proses penyelesaian perselisihan hubungan industrial diatur dalam undang-undang nomor 2 tahun 2004 tentang Penyelesaian Perselisihan Hubungan Industrial. Dalam Pasal 57 disebutkan Hukum acara yang berlaku pada Pengadilan Hubungan Industrial adalah Hukum Acara Perdata yang berlaku pada Pengadilan dalam lingkungan Peradilan Umum, kecuali yang diatur secara khusus dalam undang-undang ini.

Cara menjalankan putusan pengadilan (eksekusi) tidak diatur dalam undang-undang nomor 2 tahun 2004 sehingga eksekusi putusan pengadilan hubungan industrial mengikuti Hukum Acara Perdata yang berlaku pada Pengadilan dalam lingkungan Peradilan Umum yaitu 
Adminitrative Law \& Governance Journal Vol. 1 Edisi 3 Agustus 2018 ISSN 2621 - 2781 Online

yang diatur dalam Herzien Inlandsch Reglement (HIR) dan Rechtsreglement voor de Buitengewesten (Rbg).

Eksekusi diatur dalam pasal 195 sampai pasal 224 HIR atau pasal 206 sampai pasal 258 Rbg. Namun pada saat sekarang tidak semua ketentuan pasal-pasal tadi berlaku efektif. Yang masih betul-betul efektif berlaku terutama pasal 195 sampai pasal 208 HIR dan pasal 206 sampai pasal 240 dan pasal 258 Rbg. Sedang pasal 209 sampai pasal 223 HIR atau pasal 242 sampai pasal $257 \mathrm{Rgb}$ yang mengatur tentang "sandera" (gijzeling) tidak lagi diperlakukan secara efektif.

HIR dan Rbg adalah undang-undang hukum acara perdata peninggalan pemerintah kolonial Belanda yang saat ini masih berlaku. HIR dan Rbg saat ini sedang dalam proses perubahan dengan dibahasnya Rancangan Undang-undang Hukum Acara Perdata.

\section{Simpulan}

Berdasarkan keseluruhan uraian tersebut maka harus ada upaya untuk memberikan ruang bagi pelaksanaan eksekusi pengadilan hubungan industrial Undang Undang Nomor 2 tahun 2004 tentang Penyelesaian Perselisihan Hubungan Industrial ataupun dengan memasukan klausula khusus dalam RUU Hukum Acara Perdata yang akan dibahas pemerintah. Baik dengan cara memperkuat UU . Selama ini eksekusi putusan pengadilan hubungan industrial mandul, tidak dapat dilaksanakan. Salah satu penyebabnya adalah tidak adanya pengaturan tata cara eksekusi putusan pengadilan hubungan industrial dalam Undang Undang Nomor 2 tahun 2004 tentang Penyelesaian Perselisihan Hubungan Industrial. Penyelesaiannya diserahkan kepada tatacara eksekusi pada Herzien Inlandsch Reglement (HIR) dan Rechtsreglement voor de Buitengewesten (Rbg).

\section{Daftar Pustaka}

Hardijan, R. 2011. Hukum Ketenagakerjaan; Bogor: Ghalia Indonesia.

Husni, L., 2003. Pengantar Hukum Ketenagakerjaan Indonesia; Jakarta; PT Raja Grafindo Persada. Libertus, J., 2007. Hak-Hak Pekerja Bila di PHK; Tangerang; Praninta Offset.

Marbun, R. 2010. Jangan Mau di PHK Begitu Saja; Jakarta Selatan; Visi Media. Midah, A. 2010. Hukum Ketenagakerjaan Indonesia: Dinamika dan Kajian Teori; Bogor: Ghalia Indonesia

Sidabutar, E. S., 2004. Pedoman Penyelesaian PHK; Jakarta; PT. Raja Grafindo Persada; . Sunyoto, D., 2010. Hak Dan Kewajiban Bagi Pekerja Dan Pengusaha; Yogyakarta; Pusaka Yustisia.

Wijayanti, A., 2009. Hukum Ketenagakerjaan Pasca Reformasi; Jakarta; PT. Sinar Grafika. 
Wijayanti, A., 2012.Sinkronisasi Hukum Perburuhan Terhadap Konvensi ILO; Bandung: Karya Putra Darwati Bandung.

Zainal, dkk., A. 1994. Dasar-Dasar Hukum Perburuhan; Jakarta; PT Raja Grafindo Persada.

Zaeni, A. 2008. Hukum Kerja: Hukum Ketenagakerjaan Bidang Hubungan Kerja; Jakarta: Rajawali Pers.

Undang-Undang Nomor 2 Tahun 2004 tentang Penyelesaian Perselisihan Hubungan industrial

Kepmen No. 255 Tahun 2003 tentang Tata Cara Pembentukan dan Susunan Keanggotaan Lembaga Kerjasama Tripartit 